\title{
NEUROMECHANICAL CHARACTERIZATION OF BRAIN DAMAGE IN RESPONSE TO HEAD IMPACT AND PATHOLOGICAL CHANGES
}

\author{
Zolochevsky O. O., Martynenko O. V.
}

Traumatic injuries to the central nervous system (brain and spinal cord) have received special attention because of their devastating socio-economical cost. Functional and morphological damage of brain is the most intricate phenomenon in the body. It is the major cause of disability and death. The paper involves constitutive modeling and computational investigations towards an understanding the mechanical and functional failure of brain due to the traumatic (head impact) and pathological (brain tumor) events within the framework of continuum damage mechanics of brain. Development of brain damage has been analyzed at the organ scale with the whole brain, tissue scale with white and gray tissue, and cellular scale with an individual neuron. The mechanisms of neurodamage growth have been specified in response to head impact and brain tumor. Swelling due to electrical activity of nervous cells under electrophysiological impairments, and elastoplastic deformation and creep under mechanical loading of the brain have been analyzed. The constitutive laws of neuromechanical behavior at large strains have been developed, and tension-compression asymmetry, as well as, initial anisotropy of brain tissue was taken into account. Implementation details of the integrated neuromechanical constitutive model including the Hodgkin-Huxley model for voltage into ABAQUS, ANSYS and in-house developed software have been considered in a form of the computer-based structural modeling tools for analyzing stress distributions over time in healthy and diseased brains, for neurodamage analysis and for lifetime predictions of diseased brains. The outcome of this analysis will be how the neuromechanical simulations applied to the head impact and brain tumor therapies may assist medical specialists with their decisions during planning and application of medical surgeries.

KEY WORDS: brain damage, neuromechanics, head impact, brain tumor, modeling, simulation

\section{INFORMATION ABOUT AUTHORS}

Zolochevsky Alexander, D. Sc., Head of Laboratory, Research and Industrial Center «Polytech», 14, O. Yarosha st., Kharkiv, Ukraine, 61145, e-mail: zolochevsky55@ukr.net, ORCID ID: https://orcid.org/0000-0001-6632-4292

Martynenko Alexander, D. Sc., Professor, Department of Hygiene and Social Medicine, V. N. Karazin Kharkiv National University, 6, Svobody sq., Kharkiv, Ukraine, 61022, e-mail: Alexander.v.martynenko@karazin.ua, ORCID ID: https://orcid.org/0000-0002-0609-2220

\section{INTRODUCTION}

The functional state of the central nervous system (brain and spinal cord) is strongly dependent on adequate delivery of the main substrates, such as glucose and oxygen cerebral blood flow [1]. The decrease of these main substrates below a certain threshold for certain period of time may initiate destruction of the structural integrity of the brain. The upper level was termed as the flow threshold for failure of neuronal function while the lower level as the flow threshold for brain damage [1]. Thus, analysis to define the failure of neuronal function (total brain failure) requires the consideration of the damage accumulation in brain. In this way, determination of the flow threshold leads to the identification of the functional and morphological damage [1]. Studies to establish the threshold for the function of the whole brain are related to the consideration of the functional damage, as in the case of the traumatic brain injury. Traumatic brain injury results from a transfer of mechanical energy into the brain from traumatic events, such as head impact, rapid acceleration and deceleration in car accidents, or an explosive blast [2]. Morphological damage occurs when the consideration of the brain dysfunction exhibits the time dependence of process, as in the case pathological events due to brain tumor. As known [3], brain cancer is a very serious and dangerous disease because of their devastating socio-economical cost.

The structural irreversible changes may be 
found in the brain as the indicators of the functional and morphological damage. So, one of the main functions of tau proteins is to regulate the neuronal stability [4]. However, after head impact it is possible to see (Fig. 1) damage in a form of the aggregation of misfolded tau proteins around small blood vessels in the brain. The evolution of this damage over time is shown in Fig. 2 a, b, c and $d$. Damage initiates through the focal accumulation of tau protein tangles at the depth of cerebral sulci (Fig. 1 a) [4], and then misfolded tau proteins propagate to the closely surrounding cortex (Fig. $1 \mathrm{~b}$ ). In the following stage (Fig. 1 c) protein misfolding is broadly spreads across the brain. Finally (Fig. $1 \mathrm{~d}$ ), tau pathology affects the entire cerebral cortex and triggers brain atrophy, and total brain fracture occurs [4].

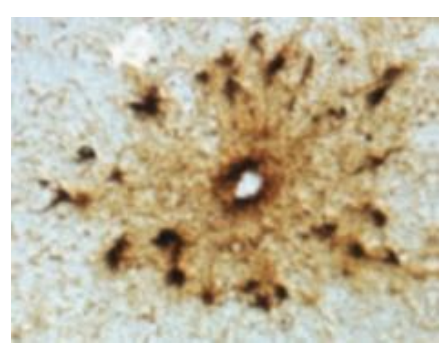

Fig. 1. Focal perivascular epicenter of neurofibrillary tangles in the frontal neocortex of postmortem brain affected by chronic traumatic encephalopathy [4]

Fourier transform infrared (FTIR) spectra of RNA isolated from tumor brain (glioma) and DNA isolated from low-dose gammairradiated epididymis cells of rats from the Chernobyl accident zone have been investigated in [5]. Observed changes in the FTIR spectra represent the damage in the primary, secondary and tertiary structure of nucleic acid.

The importance of such discipline as biomechanics is well recognized as a foundation for further experimental and theoretical studies of bone $[6,7]$ and heart [8]. At present, biomechanics of the brain combined with neurophysiology (neuromechanics) is very multidisciplinary research area with a broad range of techniques, ranging from traditional mechanical engineering techniques (mechanical testing, constitutive, mathematical, and computational modeling) to emerging imaging technique (magnetic resonance elastography) and biological (biophysical) techniques (atomic force microscopy, cellular patch clamp biophysics, and electrophysiology) [9]. However, during many years the brain had been largely neglected by biomechanics [10]. The first studies of the mechanical properties of the brain in the late 1960 s were motivated by the increasing number of traumatic brain injuries resulting from the car accidents. The first finite element models of the brain appeared in the early 1980s [11].

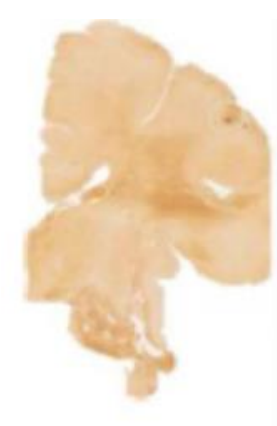

$\mathbf{a}$

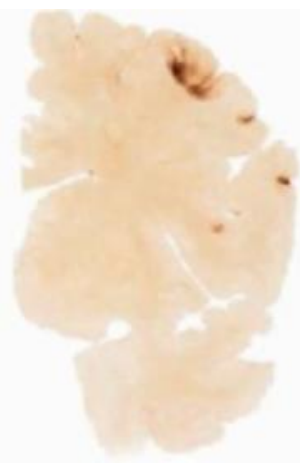

b

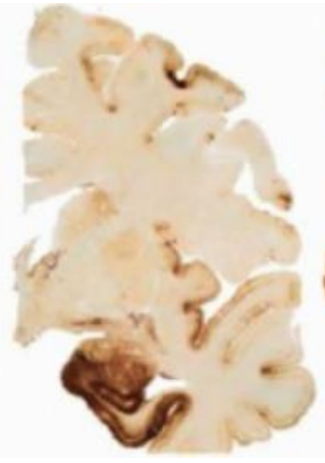

c

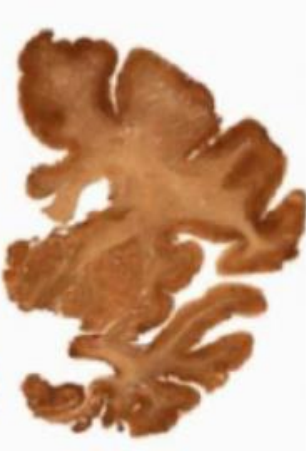

d

Fig. 2. Four characteristic stages of chronic traumatic encephalopathy ranging from focal pathology in initial stages (a, b, and c) to widespread inclusions and neurites in final stage (d) [4] 
The human brain is a complex structure (Fig. 3) made up gray matter, white matter, blood vessels, membranes, fissures and voids surrounded by, or filled with, cerebrospinal fluid [12-14]. In other words, brain tissue is highly heterogeneous, and, as mentioned above, it includes white and gray matter. Gray matter regions contain mainly neurons, and white matter regions contain mainly axons. Axons are the protrusions of neurons, and they carry electrophysiological and chemical signals through the brain.

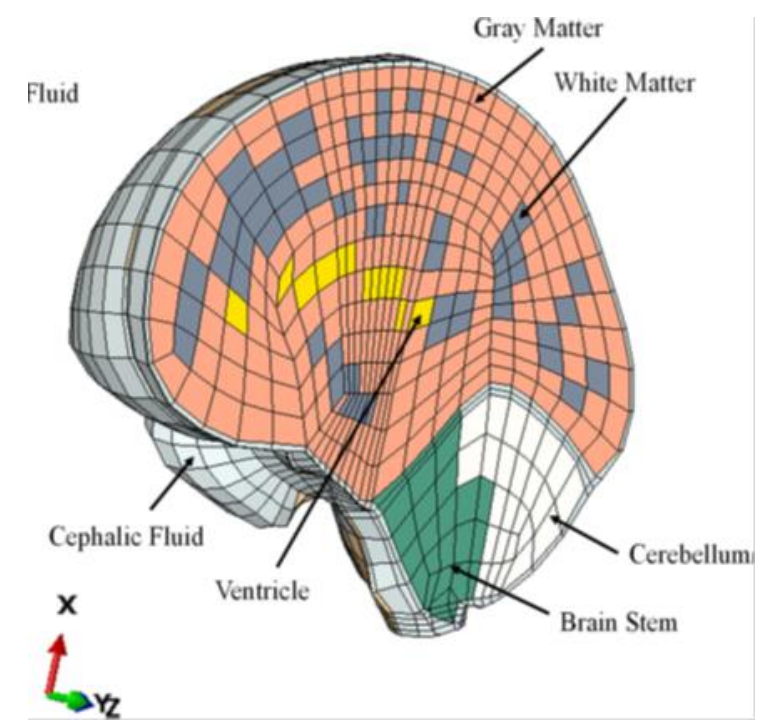

Fig. 3. A three-dimensional finite element model of the brain $[12,13]$

At present, modeling in brain neuromechanics has been developed on the organ scale with the whole brain (Fig. 4a), tissue scale with white and gray tissue (Fig. 4b), and cellular scale with an individual neuron (Fig. 4c) [15].

Most of the studies in brain neuromechanics are mainly focused on the brain response due to traumatic brain injury caused by head impact [16]. Starting since the model of Mendis [17], researchers are trying to employ nonlinear viscoelastic properties of brain at large strains. Differences in brain response due to frontal and lateral impacts were investigated in [18]. It was shown that shear stress in the brain was much higher in a lateral impact in comparison with a frontal impact. Finite element analyses with a human head/brain model are given in [19] using the LS-DYNA software and constitutive model of brain parenchyma taking account of strain rate dependency with initial anisotropy. In the following [20], the characteristic features in the unloading process of brain were introduced additionally into brain injury prediction. A geometrically detailed finite element head/brain model was proposed in [21]. These brain features considered in [21] are important to predict specific injuries such as brain contusions.

The studies in [22] were conducted using a well-known nonlinear explicit dynamics finite element code LS-DYNA. In this way, four approaches for modeling the brain-skull interface were applied. Hence, the following brain-skull interface models were used, such as, direct representation of the brain meninges and cerebrospinal fluid, outer brain surface rigidly attached to the skull, frictionless sliding contact, and a layer of spring-type cohesive elements between the brain and skull. Also, four constitutive models for the brain tissue in the numerical simulations were considered, such as, neoHookean hyperviscoelastic, Ogden hyperviscoelastic, Mooney-Rivlin hyperviscoelastic and linear viscoelastic models. The obtained results show that accurate prediction of risk of brain injury may require representation of the meninges and cerebrospinal fluid in the modeling, as well as, application of hyperviscoelastic (preferably Ogden-type) model for the brain. A wrong targeted mechanism may be selected to predict the risk of sustaining brain injuries upon impacts $[11,23]$. Then, the model predictions may not represent the 
true responses of the brain. Thus, researchers must utilize high-quality brain models and have complete understanding of the underlying injury mechanisms $[11,23]$.

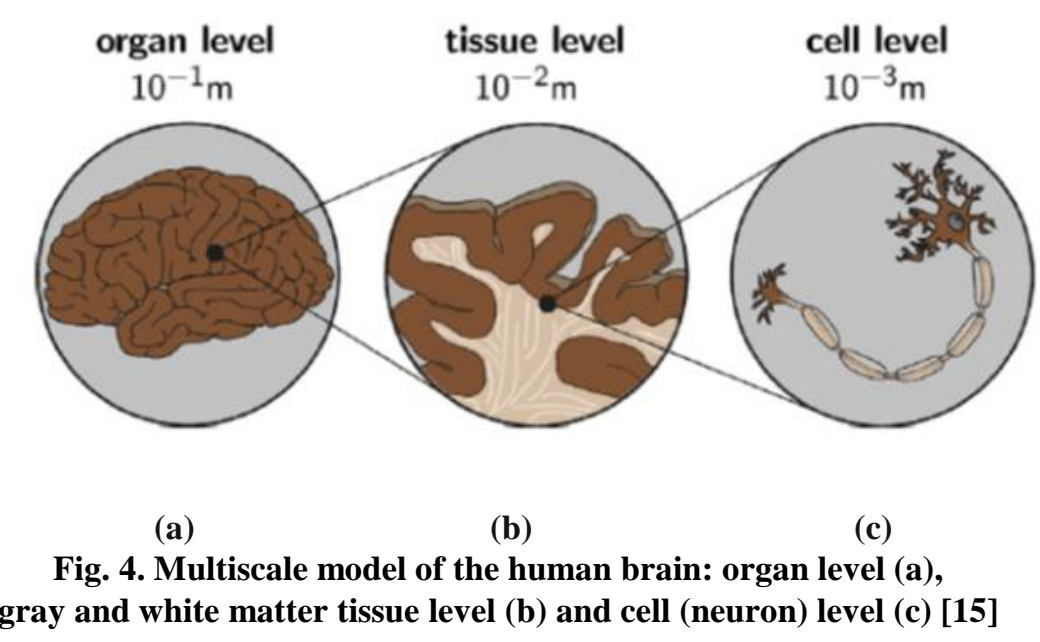

The cerebrospinal fluid is one of the most challenging features to represent correctly in a finite element model of the brain and head. Currently, researchers often employ a solid element, Lagrangian mesh representation of the cerebrospinal fluid, sometimes achieving fluid-like responses through manipulation of material properties in modeling injuries [24]. The approach given in [24] presents combination of a hybrid smoothed particle hydrodynamics and finite element model. However, limitations of this framework make further study necessary in investigating the accuracy and effectiveness of this approach. A comprehensive review of the numerical methods implemented in 16 brain finite element models during impact was performed in [25]. A mechanics-based brain damage framework developed in [26] has been able to correlate chronic traumatic encephalopathy pathology in deceased National Football League players (USA) to the damage nucleation, growth and coalescence mechanisms within the brain tissue.

Computational neuromechanical models may find also applications in modeling the development of structural diseases of the brain, for example, for computer simulation of brain deformation affected by tumor [27]. Such application for neurosurgical simulation and brain image registration was considered in detail in [28]. Computation of the brain shift in response to tumor growth was done. Hence, two constitutive models for the brain were considered, such as, neo-
Hookean hyperviscoelastic and Ogden hyperviscoelastic models. Recent review [29] presents experience accumulated during 23 years for analyses of surgical simulation problems that involve large deformations, nonlinear brain properties and nonlinear boundary conditions. However, accurate computations of the displacement field only are given in [27-29]. Precise stress computation is not considered here. Additionally, the computational results are available to an operating surgeon in less than $40 \mathrm{~s}$. The computational monitoring in real time is important, but the long-term deformations of healthy and diseased brains were not analyzed in [27-29].

Simulation of a promising treatment approach for brain related to the long-lasting drug infusion process was considered in [3036]. This problem is well known as convection-enhanced drug delivery. In this way, drug infusion processes in brain tumor therapies were analyzed. The fluid phase of brain tissue was taken into account by using a biphasic constitutive model. Various constitutive relations of poroelasticity and poroviscoelasticity were developed. Transport of therapeutic agent in the brain was studied. Again, the long-term deformations of diseased brains, as well as, the evolution of stresses were not considered here.

Although the short-term biomechanical behavior of diseased brains after infusion of a therapeutic agent into brain is impressive, the long-term characteristic features of brain after 
drug delivery are still unknown. The finite element investigations related to the lifetime prediction studies after such treatment have not been published so far.

Biomechanical behavior of healthy and diseased brains can be associated with the several load and time dependent phenomena, such as, elastoplastic deformation, creep deformation, swelling and damage growth. These phenomena can be investigated experimentally in healthy and diseased brains.

\section{MATERIALS AND METHODS}

Stress-Strain Diagrams. Mechanically, the brain tissue behaves identically to any other soft material in that it undergoes large deformation when subject to an external load. Mechanical properties of brain are studied on the samples in basic experiments, such as, compression, tension, shear and indentation.

The Young's modulus and Poisson ratio of white matter are [37] $E=350 \mathrm{~Pa}$ and $v=$ 0.35 , respectively. These values were obtained from experimental results for

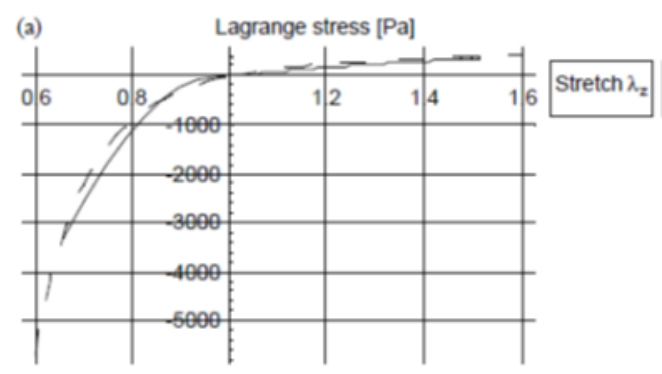

compression test on the calves brain specimens. Indentation tests of bovine brain tissue revealed that white matter is approximately one-third stiffer than gray matter [38], i.e., $E=1.895 \mathrm{kPa}$ for white matter and $E=1.389 \mathrm{kPa}$ for gray matter.

Stress-strain diagrams for swine brain tissue in tension and compression [39] are given in Fig. 5 a, $b$ for the two values of the strain rate. The specimens used in the experiments consisted of the white matter and grey matter. The measurement results indicate that brain tissue properties in tension are very different to those in compression. Furthermore, stresses are significantly higher in compression than in tension, i. e., brain tissue is stiffer in compression than in tension. Also, comparison of the experimental data with the Ogden-type model predictions has been shown in Fig. 5 a, b. Therefore, such model can be applied to finite element computations using ABAQUS, which contains built-in commands to model Ogdentype hyperelasticity.

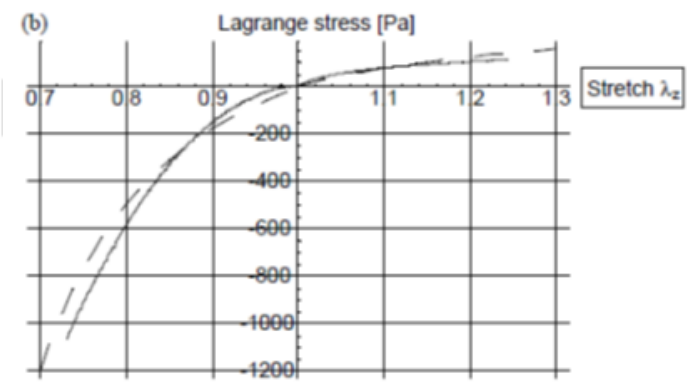

Fig. 5. Experimental (solid line) versus theoretical (dashed line) stress-strain curves for brain tissue in tension and compression at strain rates: $0.64 \mathrm{~s}^{-1}$ (a) and $0.64 \times 10^{-2} \mathrm{~s}^{-1}$ (b) [39]

The results given in Fig. 6 are obtained for porcine brain tissue tested in simple shear experiments [40]. Tests include loading, unloading and further loading in the opposite direction. It is clear (Fig. 6) that total strain in the brain tissue includes linear elastic part, nonlinear elastic part and plastic (permanent) part.

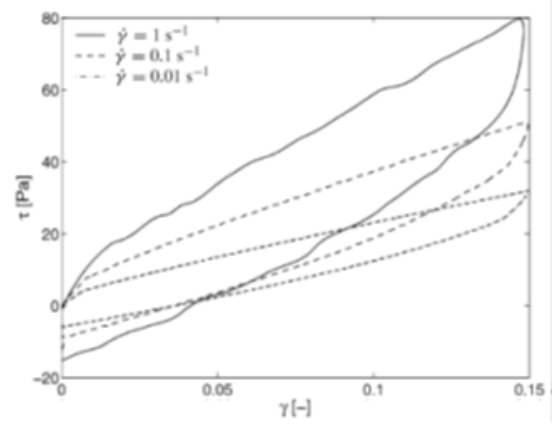

Fig. 6. Stress-strain response of brain tissue obtained during constant shear rate experiments at three different constant values of shear rates [40] 
Figure $7 \mathrm{a}, \mathrm{b}$ illustrates that human brain tissue in the field of large strains, studied experimentally in [41], not only stiffens with increasing strain, but also with increasing strain rate, as well as, that white matter is stiffer than gray matter. This conclusion coincides with one given in [14]. Also, the brain tissue had been shown to deviate from linearity at strains greater than $0.3 \%$. Same remark was given in [10].

Using tension-compression and compression-tension tests it was found [42] that the human white matter is stiffer during loading than during unloading (Fig. $8 \mathrm{a}, \mathrm{b}$ ). Additionally, white matter shows different behavior in tension and compression, and permanent (plastic) strain occurs in the process of deformation. Also, brain deforms similarly to filled rubber, and demonstrates Mullins effect and hysteresis under cyclic loading [42]. Brain deformation found during cyclic loading can be described by the Ogden-type model as well. The stiffness of axonal fibers is about 10 times higher than the brain matrix stiffness at $50 \%$ stretch.

The comparison of the experimental data in tension and compression (Figs. 5 and 8) shows the effect of the kind of stress state on the processes of deformation of the brain tissue. Thus, it is possible to conclude that the brain tissue belongs to the broad class of the materials with different behavior under tensile and compressive loading types [4348].

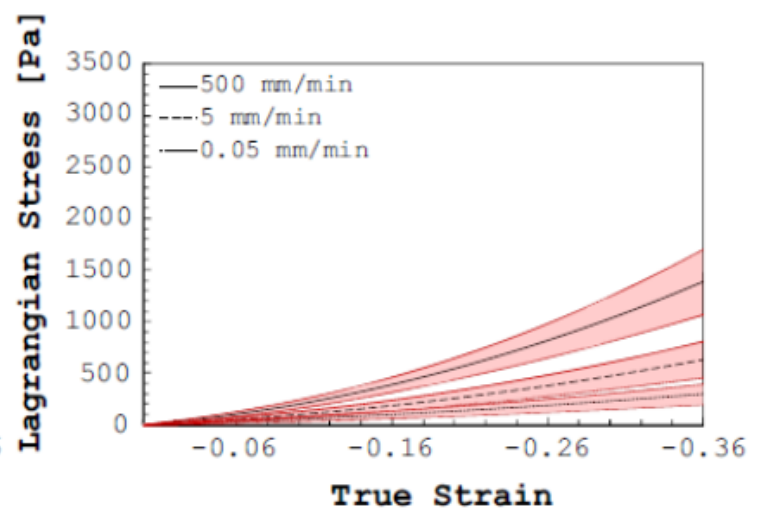

b

Fig. 7. Compression tests on human grey (a) and white matter (b) at three different constant values of strain rates, height of cylindrical specimens is $7 \mathrm{~mm}$ [41]

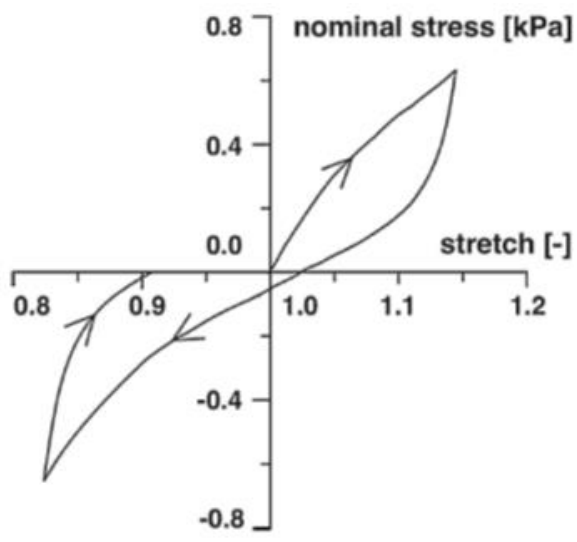

$\mathbf{a}$

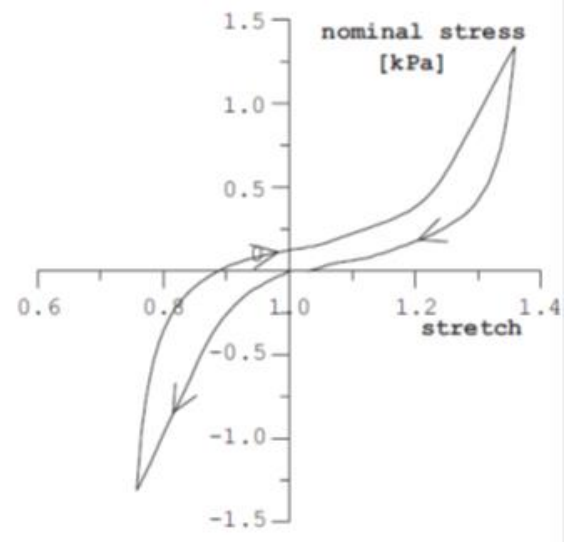

b

Fig. 8. Nominal stress versus uniaxial stretch response of tension-compression test (a) and compression- tension test (b) performed on prismatic specimens of human white matter [42]. Arrows indicate the loading direction

As mechanical properties of brain tissue are becoming more accurately characterized, the pronounced anisotropy (rather as transverse isotropy) of white matter becomes 
more apparent due to its oriented axonal tracts [49-55], while grey matter has been observed to be isotropic [55]. Thus, according to the experimental data given in [49-55] white matter belongs to the initially anisotropic materials with different behavior in tension and compression [56-62]. On the other hand, no influence of anisotropic nerve fiber distribution on the mechanical response of the brain tissue in shear, compression and tension was found in [63]. The general conclusion given in [63] is that the human brain tissue is nearly isotropic.

Brain Creep. The most of the in vitro tests used in creep analysis of brain are compression creep tests, and stress relaxation tests in compression and shear [64]. The first in vitro brain creep tests were performed on mouse brain samples under compressive loading type [65]. The creep curves have two distinct regimes (primary and secondary) by analogy with the engineering materials (steels, cast irons, light alloys) at high

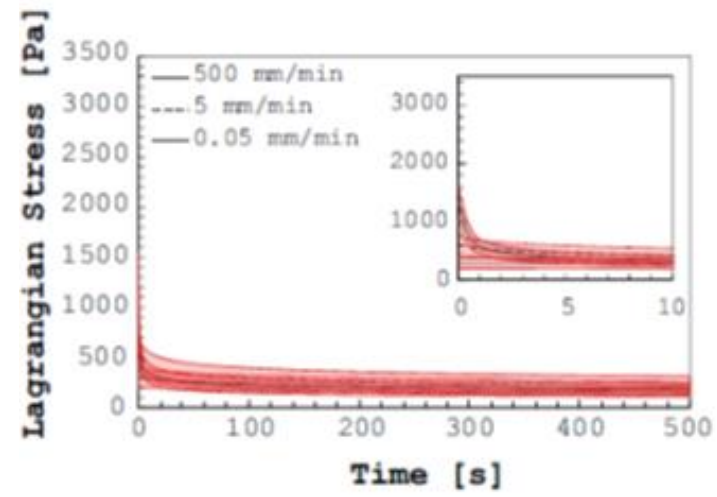

a temperatures. In the following, creep tests in compression, and stress relaxation tests in compression were performed on human and monkey brain [66]. The stress exponent in the Norton law was found to be one, and the creep strains in brain were small.

Stress relaxation after compression in the field of large strains was studied experimentally in [41] on human white matter and gray matter. These experimental results are given in Fig. 9 a, b. Stress relaxation tests in [67] were performed after compression and shear on the specimens taken in four regions of human brain. The further research obtained on the ten tested human brain slices has been discussed in [68].

Brain tissue demonstrates different stress relaxation response after tension and compression [54, 69-71], and, therefore, it represents the broad class of the materials with different creep behavior under tensile and compressive loading types [72-79].

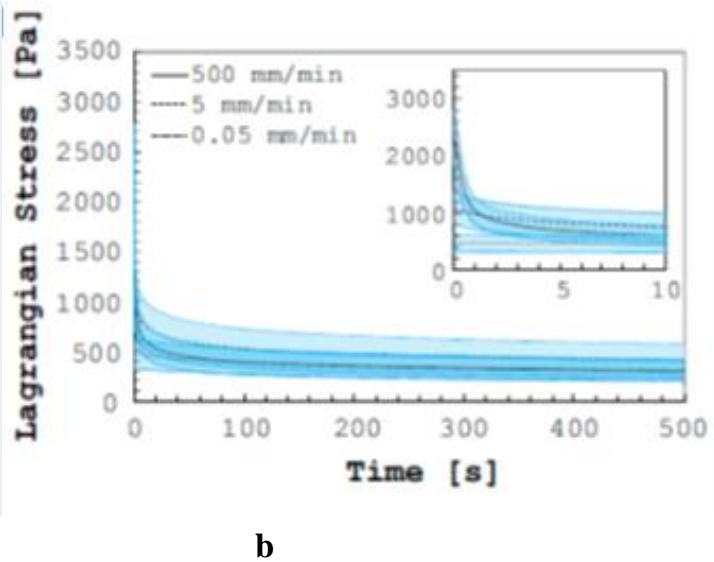

b

Fig. 9. Stress relaxation tests on human grey (a) and white matter (b) at three different constant values of strain rates, height of cylindrical specimens is $7 \mathbf{~ m m ~ [ 4 1 ] ~}$

Brain Swelling. Brain swelling, or edema, occurs when there is an abnormal accumulation of water within the brain tissue $[80,81]$. Edema is a significant cause of morbidity and death [82]. Therefore, current medical strategies aim to reduce brain swelling in order to maintain blood supply and retain cerebral metabolism [83]. As known [84-88], swelling is a characteristic feature of many materials with defects of the microstructure. The water transport in the brain, as well as, transport of therapeutic agent in the brain with tumor can be described under assumption of Fickian diffusion [89-92] or non-Fickian diffusion [93].

Experiments on rat brain slices were performed by Elkin et al. [94], and the volume of the slices was measured when brain swelling occurred. The value of this volume change was found to be about $75 \%$. It was proposed [94] that brain tissue swelling observed experimentally is caused by fluid moved from the ionic solution into the porous medium, i. e., by an accumulation of nonpermeating (electrically) neutral solutes within the tissue.

However, in the experiments of Elkin et al. [94] brain swelling evolved over several 
hours. This suggests that brain swelling under study is maybe related to the biological processes that determine the swelling rate, such as, the fixed negative charges in the brain due to macromolecules (proteoglycans and DNA) rather than physical processes, such as, the rate of movement of water [95, 96].

Below brain swelling will be considered from the neuromechanical point of view. For this purpose, we start from the classical work by Hodgkin and Huxley [97] used the voltage-clamp technique to investigate the mechanisms for conduction of the nerve impulse and generation of the action potential in the squid giant axon. In this way, they developed their model known as HodgkinHuxley model [97]. Action potential generation was caused by the unequal distribution of ions, particularly $\mathrm{K}^{+}, \mathrm{Na}^{+}$and $\mathrm{Cl}^{-}$, across the single axon. It was found [97] that axon has a threshold for the initialization of the action potential of about -45 to -55 $\mathrm{mV}$. The geometry of the axon can be modeled as a cylinder (Fig. 10a) with a thin wall representing the axon membrane with a constant thickness. The Hodgkin-Huxley model was used to calculate the changes of voltage field during an electrophysiological pulse for unmyelinated axons and the Nodes of Ranvier of myelinated axons (Fig. 10b) [98].

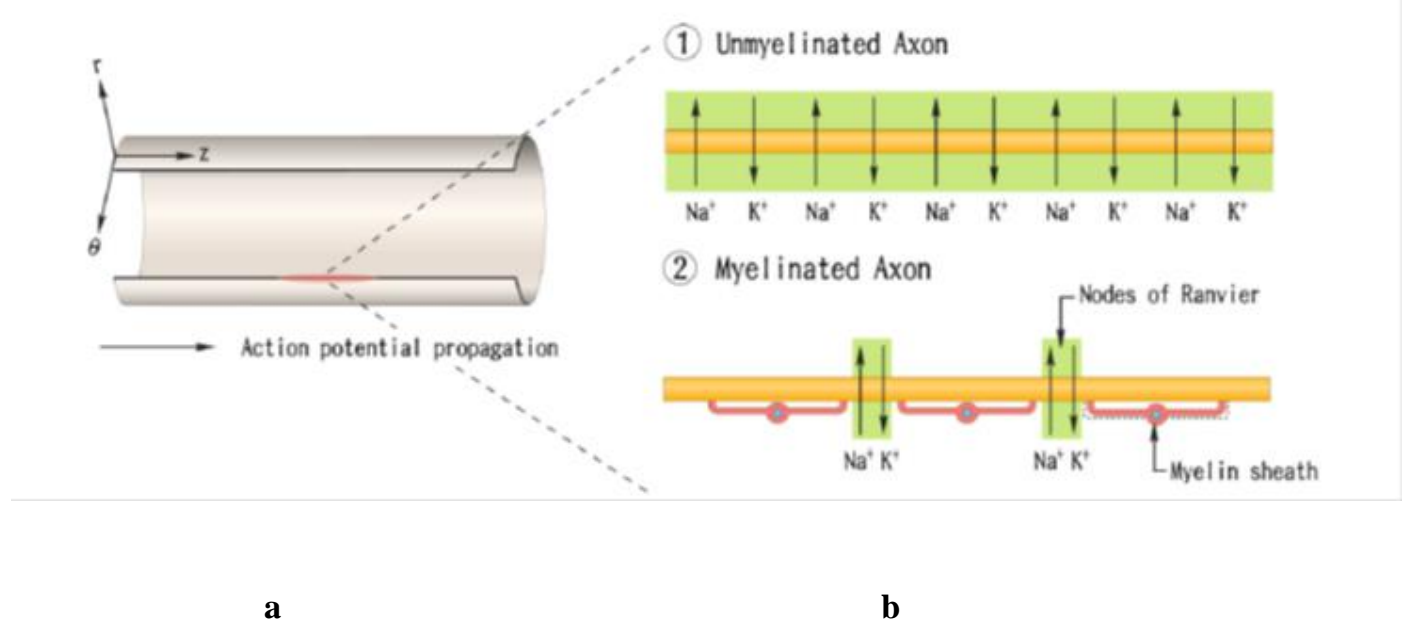

Fig. 10. Representation of the axon in a local cylindrical coordinate system (a) with two scenarios for consideration (b): unmyelinated axons (1) and myelinated axons (2) [98]

Initially, swelling of cell membranes associated with action potential was measured for squid giant axons [99-101] and HEK293 cells $[102,103]$. Then swelling of biological membranes has been observed experimentally in many neuronal and non-neuronal cells [104]. The review of these investigations can be found in [105].

Brain Damage. The neurodamage in brain is a naturally occurring event that appears at the reference state, at least, in a form of voids and fissures. In general, defects of brain microstructure can be classified as point, linear, planar (interfacial) and volume defects. In this regard, there are four distinct varieties of neurodamage in brain, respectively. These types of brain damage are distinguished by their morphology and location, as well as, the nature of the neurological and mechanical stimuli that cause them to form.

From the continuum damage mechanics point of view [106-111], neurodamage decreases stiffness and strength of brain tissue, and eventually leads to collapse of whole brain. In this sense, neurodamage deteriorates the mechanical properties of brain.

Two mechanisms of brain tissue damage have been discussed by Lang [96]. The first one is axonal stretch [112]. Thus, mechanical deformation can cause axonal stretch, hence, preventing the brain from functioning [96, 112].

The second one is compression of capillaries leading to hypoxia and subsequent cell death [95]. In this case, brain damage will be tracked by the compressive stress within the tissue. 
As an example, schematic of damage mechanisms $[96,113]$ by which local ischemia can cause the ischemic region to propagate through the brain is given in Fig. 11.

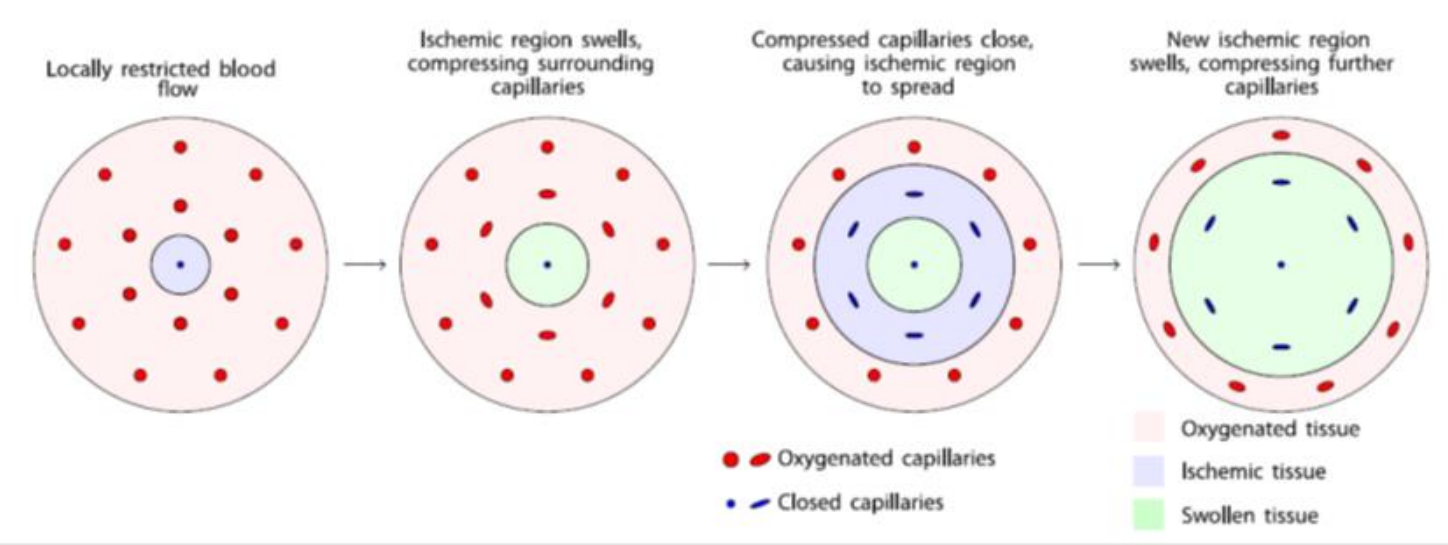

Fig. 11. Schematic of the mechanism by which local edema and oxygen delivery can cause tissue damage to propagate through healthy brain tissue $[96,113]$

Recently, magnetic resonance elastography (MRE) has been widely applied to brain in order to determine whether local changes in mechanical properties might arise during development of cancer [114]. In this way, it was found (Fig. 12) that brain tumor from a patient with a meningioma is stiffer than the surrounding healthy tissue.

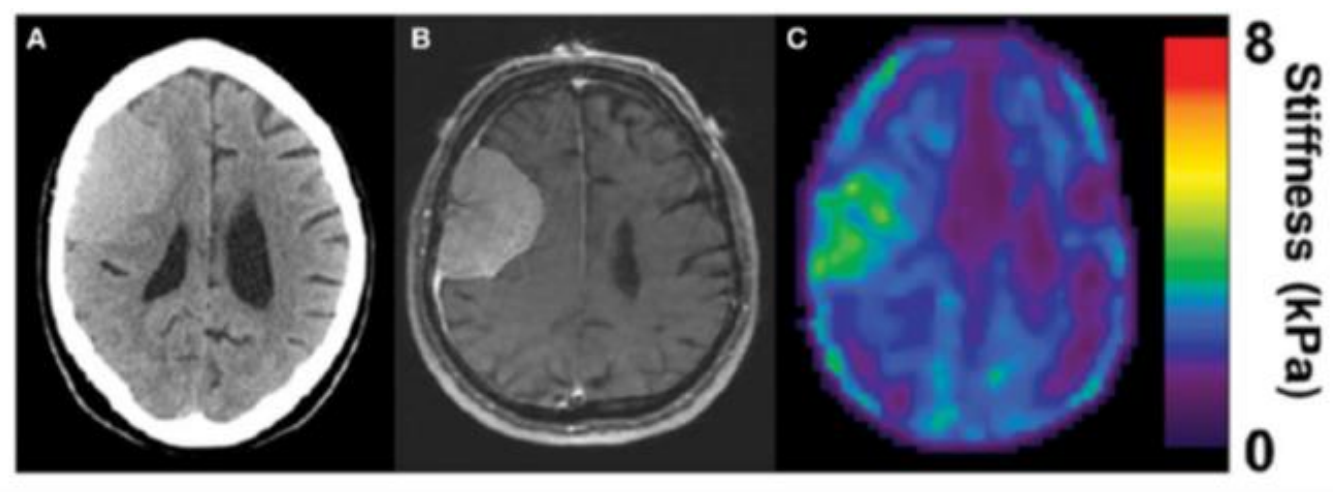

Fig. 12. Stiffening of meningioma as measured by MRE : CT image of the head (A), corresponding MRI (B) and corresponding MRE image (C) showing homogenous tumor with the stiffness greater than surrounding healthy tissue (in green) [114]

Similarly, the stiffness of neuronal cells increases after treatment with amyloid- $\beta$ protein, which is considered as the prime suspect for initiating the neuronal dysfunction in Alzheimer's disease [115]. Thus, development of new approaches to find the relationship between brain cell architecture, infused drug, biological environment, mechano-electrophysiological loading, damage growth and damage repair in diseased brain could be an important area of focus in neuromechanics.

Neuromechanics. Let $x_{i}(i=1,2,3)$ denote coordinates of a material point in the initial (undeformed) configuration of the brain tissue, while $X_{i}$ are its coordinates in the deformed (current) configuration at a given instant of time $t(t \neq 0)$. Assume, for simplicity, that the initial configuration of the brain tissue and its current configuration are referred to the same coordinate frame $x_{i}(i=1,2,3)$.

In the Lagrangian formulation of the neuromechanical model at large strains it is necessary to introduce the Cauchy-Green strain tensor as an important strain measure in the reference configuration of the brain tissue in the following form [116]: 


$$
\varepsilon_{i j}=0.5\left(u_{i, j}+u_{j, i}+u_{k, i} u_{k, j}\right),
$$

where $u_{i}\left(x_{1}, x_{2}, x_{3}, t\right)=X_{i}-x_{i} \quad$ are the components of the displacement vector of the material points at time $t$ in directions $x_{1}, x_{2}, x_{3}$, respectively. It is not difficult to obtain the material time derivative of the Cauchy-Green strain tensor

$$
\dot{\varepsilon}_{i j}=0.5\left(\dot{u}_{i, j}+\dot{u}_{j, i}+u_{k, i} \dot{u}_{k, j}+u_{k, j} \dot{u}_{k, i}\right),(i, j, k=1,2,3)
$$

where the dot above the symbol denotes a material time derivative. The rate of strain tensor in the current brain configuration can be defined as [116]:

$$
d_{i j}=0.5\left(\frac{\partial \dot{u}_{i}}{\partial X_{j}}+\frac{\partial \dot{u}_{j}}{\partial X_{i}}\right)
$$

The connection between $\varepsilon_{i j}$ and $d_{i j}$ has a form [116]:

$$
\dot{\varepsilon}_{i j}=\frac{\partial X_{k}}{\partial x_{i}} \frac{\partial X_{l}}{\partial x_{j}} d_{k l}
$$

or

$$
d_{i j}=\frac{\partial X_{k}}{\partial x_{i}} \frac{\partial X_{l}}{\partial x_{j}} \dot{\varepsilon}_{k l} .
$$

Then the additive decomposition of the time derivative of the total Cauchy-Green strain tensor and of the rate of strain tensor acting on the current brain configuration to a linear elastic part, nonlinear elastic part, plastic part, creep part and swelling one may be postulated, respectively, in the following form:

$$
\dot{\varepsilon}_{i j}=\dot{\varepsilon}_{i j}^{e}+\dot{\varepsilon}_{i j}^{n e}+\dot{\varepsilon}_{i j}^{p}+\dot{\varepsilon}_{i j}^{c}+\dot{\varepsilon}_{i j}^{s}
$$

and

$$
d_{i j}=d_{i j}^{e}+d_{i j}^{n e}+d_{i j}^{p}+d_{i j}^{c}+d_{i j}^{s} .
$$

The second Piola-Kirchhoff stress tensor $\tau_{i j}$ in the brain tissue can be expressed in term of the Cauchy stress tensor $\sigma_{i j}$ such that [116]

$$
\tau_{i j}=J \sigma_{k l} \frac{\partial x_{i}}{\partial X_{k}} \frac{\partial x_{j}}{\partial X_{l}}
$$

and

$$
\sigma_{i j}=J^{-1} \tau_{k l} \frac{\partial X_{i}}{\partial x_{k}} \frac{\partial X_{j}}{\partial x_{l}},
$$

where $J$ is the Jacobian of deformation; $\mathbf{F}$ is the matrix of the deformation gradients in the current configuration at time $t ; J=\operatorname{det} \mathbf{F}$;
$\mathbf{F}=\left[\frac{\partial X_{i}}{\partial x_{j}}\right]=\left[\delta_{i j}+u_{i, j}\right],(i, j=1,2,3) ; \quad \delta_{i j} \quad$ is the

Kronecker delta.

Now we introduce objective stress rate, such as, the Truesdell derivative $\sigma_{k l}^{\operatorname{Tr}}$ of the Cauchy stress tensor which is essential in order to formulate the constitutive equations of the brain behavior in the rate form. Note also that the material time derivative of the Cauchy stress tensor $\sigma_{k l}$, i.e. $\sigma_{k l}$, is affected by rigid-body motions, and it is not objective (not frame-indifferent) [116]. The Truesdell derivative of the Cauchy stress tensor and the material derivative of the second PiolaKirchhoff stress tensor are connected by the relation [116]:

$$
\dot{\tau}_{i j}=J \sigma_{k l}^{\mathrm{Tr}} \frac{\partial x_{i}}{\partial X_{k}} \frac{\partial x_{j}}{\partial X_{l}},
$$

which is similar to (8). Then the relation between $\sigma_{k l}^{\operatorname{Tr}}$ and $d_{i j}^{e}$ will be accepted in such a form

$\sigma_{k l}^{\mathrm{Tr}}=A_{k l r s}^{*}\left(d_{r s}-d_{r s}^{n e}-d_{r s}^{p}-d_{r s}^{c}-d_{r s}^{s}\right)$.

Here $A_{k l r s}^{*}$ is the symmetrical tensor of the appropriate elastic constants. By substituting Eq. (11) into Eq. (10) and then taking into account Eq. (5) we obtain

$$
\dot{\tau}_{i j}=A_{i j k l}\left(\dot{\varepsilon}_{k l}-\dot{\varepsilon}_{k l}^{n e}-\dot{\varepsilon}_{k l}^{p}-\dot{\varepsilon}_{k l}-\dot{\varepsilon}_{k l}^{s}\right),
$$

where

$$
A_{i j k l}=J A_{m n r s}^{*} \frac{\partial x_{i}}{\partial X_{m}} \frac{\partial x_{j}}{\partial X_{n}} \frac{\partial x_{k}}{\partial X_{r}} \frac{\partial x_{l}}{\partial X_{s}}(m, n, r, s=1,2,3) \text {. }
$$

It is not difficult to establish that condition $A_{i j k l}=A_{k l i j}$ of symmetry is valid.

Considering brain tissue as the anisotropic material with different behavior in tension and compression, the connection between the kinematic tensor $e_{k l}$ in the current configuration and the Kirchhoff stress tensor $T_{k l}$ can be written as follows [117-119]:

$$
e_{i j}=e_{0}\left(\frac{a_{i j k l} T_{k l}}{T_{2}}+b_{i j}\right) \text {. }
$$

Here $\quad T_{k l}=J \sigma_{k l} ; \quad e_{0} T_{e}=T_{i j} e_{i j}$; $T_{e}=T_{1}+T_{2} ; T_{1}=b_{i j} T_{i j} ; \quad T_{2}^{2}=a_{i j k l} T_{i j} T_{k l} ; \quad b_{i j}$ and $a_{i j k l}$ are the second order and fourth order material tensors; $T_{1}$ and $T_{2}^{2}$ are the linear and quadratic joint invariants of the Kirchhoff stress and the material tensors; $T_{e}$ is the equivalent Kirchhoff stress; $e_{0}$ is the scalar function which depends on $T_{e}$, as well as, some structural parameters and which 
specifies for each physical state of the brain (nonlinear elasticity, plasticity, creep).

In the case of the nonlinear elasticity, the kinematic tensor $e_{k l} \equiv d_{k l}^{n e}$ is the nonlinear elastic part of the rate of strain tensor in the current configuration, and it is necessary to specify $e_{0}$ as the function of $T_{e}$ and of some parameters affecting damage growth, deformation hardening and deformation softening in the brain under nonlinear elastic deformation.

For plastic deformation of anisotropic brain tissue, the kinematic tensor $e_{k l} \equiv d_{k l}^{p}$ in Eq. (14) is the plastic part of the rate of strain tensor in the current configuration, and it is necessary to define the conditions when $d_{k l}^{p}=0$ in the cases of elastic deformation, of unloading or neutral loading, as well as, the condition of loading.

Considering creep hardening with the measure $q$ and creep damage development with damage parameter $\omega$ for anisotropic brain tissue, it is possible to assume that the kinematic tensor $e_{k l} \equiv d_{k l}^{c}$ in Eq. (14) is the creep part of the rate of strain tensor in the current configuration, and the scalar multiplier in Eq. (14) can be defined as

$$
\begin{array}{ll}
e_{0}=\frac{v\left(T_{e}\right) \xi(q)}{(1-\omega)^{m}} . & (15) \quad \begin{array}{l}
\text { directions of aniso } \\
\text { following form }[117
\end{array} \\
e_{11}=e_{0}\left(\frac{a_{1111} T_{11}+a_{1122} T_{22}+a_{1133} T_{33}}{T_{2}}+b_{11}\right), e_{12}=2 e_{0} \frac{a_{1212} T_{12}}{T_{2}}(1,2,3) .
\end{array}
$$

Different examples on how to specify the functions $v\left(T_{e}\right), \quad \xi(q)$ and damage evolution equation for $\omega$ are given in $[109,111]$.

Now, a number of comments need to be made in reference to the constitutive model given by Eqs. (12) and (14). First, using the spin tensor

$$
\Omega_{i j}=0.5\left(\frac{\partial \dot{u}_{i}}{\partial X_{j}}-\frac{\partial \dot{u}_{j}}{\partial X_{i}}\right)
$$

and the Jaumann stress derivative [116] $\sigma_{i j}^{\mathrm{J}}=\sigma_{i j}-\Omega_{i r} \sigma_{r j}+\sigma_{i r} \Omega_{r j}$ instead of the Truesdell stress derivative in Eq. (11) does not provide satisfaction of the symmetry condition $A_{i j k l}=A_{k l i j}$. Second, the tensor relationship defined by Eq. (14) was used in [120-127] for modeling of the biological tissues, however, without referencing sources [117-119]. Third, the present model reflects the characteristic features of the anisotropic bimodular materials [128, 129]. Finally, the model under discussion can be extended to the case of the anisotropic creep hardening under nonproportional loading according to the approaches [130,131].

For orthotropic materials with coincidence of the coordinate axes with the principal directions of anisotropy Eq. (14) takes the following form [117-119]:

Here the symbol $(1,2,3)$ means that the rest of the relations can be obtained from Eq. (16) by circular transposition of lower indexes 1, 2 and 3;

$$
\begin{gathered}
T_{2}^{2}=a_{1111} T_{11}^{2}+a_{2222} T_{22}^{2}+a_{3333} T_{33}^{2}+2 a_{1122} T_{11} T_{22}+2 a_{1133} T_{11} T_{33}+2 a_{2233} T_{22} T_{33}+4 a_{1212} T_{12}^{2}+4 a_{1313} T_{13}^{2}+4 a_{2323} T_{23}^{2}, \\
T_{1}=b_{11} T_{11}+b_{22} T_{22}+b_{33} T_{33} .
\end{gathered}
$$

Further simplification of Eqs (16), (17) for orthotropic materials when the coordinate axes coincide with the principal directions of anisotropy is related to the following requirements [132, 133]

$$
a_{1111}=a_{11}^{2}, 2 a_{1122}=-a_{11} a_{22}, 4 a_{1212}=3 a_{11} a_{22}+a_{12}^{2}(1,2,3)
$$

using the six material parameters $a_{11}, a_{22}, a_{33}, a_{12}, a_{23}$ and $a_{13}$. Then it is easy to obtain from Eqs. (16)-(18) the following tensor relationship [133]

$$
e_{11}=e_{0}\left[\frac{a_{11}^{2} T_{11}-\frac{1}{2}\left(a_{11} a_{22} T_{22}+a_{11} a_{33} T_{33}\right)}{T_{2}}+b_{11}\right], \quad e_{12}=\frac{1}{2} e_{0} \frac{\left(3 a_{11} a_{22}+a_{12}^{2}\right) T_{12}}{T_{2}} \quad(1,2,3),
$$

where

$$
\begin{aligned}
& T_{2}^{2}=a_{11}^{2} T_{11}^{2}+a_{22}^{2} T_{22}^{2}+a_{33}^{2} T_{33}^{2}-a_{11} a_{22} T_{11} T_{22}-a_{11} a_{33} T_{11} T_{33}-a_{22} a_{33} T_{22} T_{33}+\left(3 a_{11} a_{22}+a_{12}^{2}\right) T_{12}^{2}+\left(3 a_{11} a_{33}+a_{13}^{2}\right) T_{13}^{2}+ \\
& +\left(3 a_{22} a_{33}+a_{23}^{2}\right) T_{23}^{2} .
\end{aligned}
$$


Another possible simplification of Eqs (16), (17) for orthotropic materials with coincidence of the coordinate axes with the principal directions of anisotropy is related to the requirements $a_{1111}=G_{0}+H_{0}$, $a_{2222}=F_{0}+H_{0}, a_{3333}=G_{0}+F_{0}, a_{1122}=-H_{0}, a_{2233}=-F_{0}, a_{1133}=-G_{0}, 2 a_{1212}=N_{0}, 2 a_{2323}=L_{0}, 2 a_{1313}=M_{0}$, based on the six material parameters $G_{0}, H_{0}, F_{0}, N_{0}, L_{0}$ and $M_{0}$. Then the equivalent Kirchhoff stress has a form

$$
T_{e}=T_{1}+\sqrt{H_{0}\left(T_{11}-T_{22}\right)^{2}+F_{0}\left(T_{22}-T_{33}\right)^{2}+G_{0}\left(T_{33}-T_{11}\right)^{2}+2 N_{0} T_{12}^{2}+2 L_{0} T_{23}^{2}+2 M_{0} T_{13}^{2}} .
$$

Note that the expression given by Eq. (20) has been discussed recently in [134], however, without referencing sources [117-119].

In a particular case of the transverse isotropy of white matter with a single axis of symmetry 1 the following equalities in Eqs. (16), (17) take place [135]

$$
b_{22}=b_{33}, a_{2222}=a_{3333}, a_{1122}=a_{1133}, a_{1212}=a_{1313}, a_{2222}=2 a_{2323}+a_{2233} \text {. }
$$

For gray matter tissue with the initial isotropy of mechanical properties it is necessary to accept in Eqs. (16), (17) the following conditions

$$
b_{11}=b_{22}=b_{33}, a_{1111}=a_{2222}=a_{3333}, \quad a_{1122}=a_{1133}=a_{2233}, a_{1212}=a_{1313}=a_{2323}, a_{1111}=2 a_{1212}+a_{1122} \text {. }
$$

The swelling part of the rate of strain tensor defined by Eq. (7) in the conditions of electrophysiological impairments of brain can be determined as [136, 137]

$$
d_{i j}^{s}=c_{i j} \dot{V} .
$$

Here, $V$ is the voltage across the nerve membrane, the material tensor $c_{i j}$ has to be introduced under assumption of orthotropy and coincidence of the coordinate axes with the principal directions of anisotropy, and, as earlier, the dot above the symbol denotes a material time derivative. Additionally, it is necessary to take into account that swelling is only relevant in the through-thickness direction of the nerve membrane, and zero in the longitudinal and circumferential directions [136]. The voltage across the membrane as a function of time can be found using the Hodgkin-Huxley model [97, 98, 136, 137].

The axon can be considered as a cylinder (Fig. 10a) with a radius ranging from 0.05 to

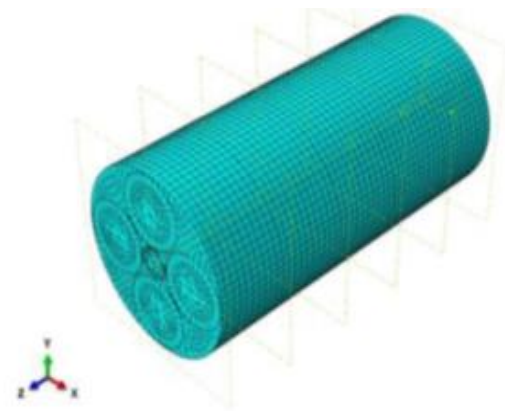

$10 \mu \mathrm{m}[138]$ and with a thickness about 3-4 $\mathrm{nm}$ [98, 137]. Neuromechanical analysis of damage in a single axon can be performed using the models of a thin shell [56, 111, 139-141] and a moderately thick shell [142, $143]$, as well as, the 3D theory [144, 145].

The electrical and mechanical phenomena were considered simultaneously in a nerve bundle (Fig. 13) in order to understand the electrophysiological changes due to trauma $[13,136]$.The electro-thermal analogy in the finite element software ABAQUS was used. It was established numerically that at high impact speed, mechanical failure occurs at lower strain values in large unmyelinated bundles than in myelinated bundles or small unmyelinated bundles [13].

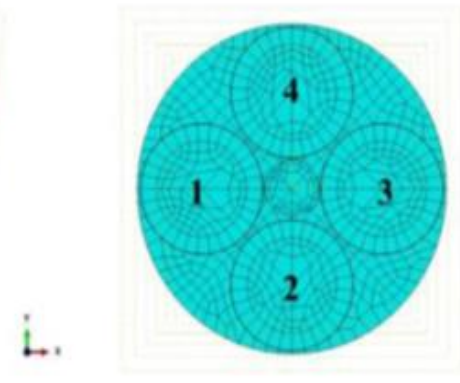

b

Fig. 13. 3D representation of the nerve bundle with four identical neurites: the isometric view (a) and the frontal view (b) [136] 
Constitutive models implemented into ANSYS $[84,88,92,146]$ and ABAQUS $[147,148]$ give the possibility to predict the mechanical and functional failure of brain due to the traumatic (head impact) and pathological (brain tumor) events within the framework of continuum damage mechanics of brain.

\section{CONCLUSIONS}

Computer-implemented modeling systems, and methods for analyzing and predicting brain behavior can overcome many of the limitations of traditional surgery. Computer-integrated surgery systems can be used as a supporting tool for diagnosis and prognosis of brain disease, as well as, for surgical simulation and image-guided neurosurgery.

The outcome of the computational analysis will be how the neuromechanical simulations applied to the head impact and brain tumor therapies may assist medical specialists with their decisions during planning and application of medical surgeries.

\section{REFERENCES}

1. Heiss, W. D. (1983). Flow thresholds of functional and morphological damage of brain tissue. Stroke, 14(3), 329-331. https://www.ahajournals.org/doi/10.1161/01.STR.14.3.329

2. Chayka, A. V., Zaben'ko, Y. Y., Labunets, I. F., Pivneva, T. A. (2017).Traumatic brain injury: pathogenesis, experimental models, prospects of cell-based therapy. Cell and Organ Transplantology, 5(1), 200-208. DOI: 10.22494/cot.v5i2.78

3. Huse, J. T., Holland, E. C. (2010). Targeting brain cancer: advances in the molecular pathology of malignant glioma and medulloblastoma. Nature Reviews Cancer, 10(5), 319-331. DOI: 10.1038/nrc2818

4. McKee, A. C., Stein, T. D., Nowinski, C. J., Stern, R. A., Daneshvar, D. H., Alvarez, V. E., Lee, H.-S., Hall, G., Wojtowicz, S. M., Baugh, C. M., Riley, D. O., Kubilus, C. A., Cormier, K. A., Jacobs, M. A., Martin, B. R., Abraham, C. R., Ikezu, T., Reichard, R. R., Wolozin, B. L., Budson, A. E., Goldstein, L. E., Kowall, N. W., Cantu, R. C. (2013). The spectrum of disease in chronic traumatic encephalopathy. Brain, 136(1), 43-64. DOI: 10.1093/brain/aws307

5. Dovbeshko, G. I., Gridina, N. Y., Kruglova, E. B., Pashchuk, O. P. (2000). FTIR spectroscopy studies of nucleic acid damage. Talanta, 53(1), 233-246.

6. Martynenko, O. V., Zolochevsky, O. O., Allena, R. (2017). Long term evolution of bone reconstruction with bone graft substitutes. The Journal of V. N. Karazin Kharkiv National University. Series «Medicine», (33), 107-118. https://periodicals.karazin.ua/medicine/article/view/9153

7. Zolochevsky, O. O., Martynenko, O. V. (2019). Biomechanical analysis of tension-compression asymmetry, anisotropy and heterogeneity of bone reconstruction in response to periprosthetic fracture repair. The Journal of V. N. Karazin Kharkiv National University, Series «Medicine», (37), 19-32. DOI: https://doi.org/10.26565/2313-6693-2019-37-03

8. Czekanski, A., Martynenko, A. V., Zozulya, V. V. (2018). Modeling of heart muscles. In Altenbach H., Öchsner A. (eds.), Encyclopedia of Continuum Mechanics (pp. 1-11).Berlin: Springer. DOI: 10.1007/978-3-662-53605-6_279-1.

9. Miller, K. (2011). Introduction. In MillerK. (ed.), Biomechanics of the Brain (pp. 1-4).New York: Springer.

10. Bilston, L. E. (2011). Brain tissue mechanical properties. In BilstonL. E. (ed.), Neural Tissue Biomechanics (pp. 11-24).Berlin: Springer.

11. Yang, K.H., King, A.I. (2011). Modeling of the brain for injury simulation and prevention. In Miller K. (ed.), Biomechanics of the Brain (pp. 91-110). New York: Springer.

12. Horgan, T. J., Gilchrist, M. D. (2003). The creation of three-dimensional finite element models for simulating head impact biomechanics. International Journal of Crashworthiness, 8(4), 353-366.

13. Cinelli, I., Destrade, M., McHugh, P., Trotta, A., Gilchrist, M., Duffy, M. (2019). Head-to-nerve analysis of electromechanical impairments of diffuse axonal injury. Biomechanics and Modeling in Mechanobiology, 18(2), 361-374. DOI: 10.1007/s10237-018-1086-8

14. Budday, S., Ovaert, T. C., Holzapfel, G. A., Steinmann, P., Kuhl, E. (2019). Fifty shades of brain: A review on the mechanical testing and modeling of brain tissue. Archives of Computational Methods in Engineering, 1-44. DOI: 10.1007/s11831-019-09352-w

15. Goriely, A., Budday, S., Kuhl, E. (2015).Neuromechanics: From neurons to brain. In Bordas S.P.A., Balint D. S. (eds.), Advances in Applied Mechanics (vol. 48, pp. 79-139). Burlington: Academic Press. DOI: $10.1016 /$ bs.aams.2015.10.002 
16. Atsumi, N., Nakahira, Y., Iwamoto, M. (2016). Development and validation of a head/brain FE model and investigation of influential factor on the brain response during head impact. International Journal of Vehicle Safety, 9(1), 1-23. DOI: 10.1504/IJVS.2016.077145

17. Mendis, K. (1992). Finite Element Modeling of the Brain to Establish Diffuse Axonal Injury Criteria. Ph.D Thesis, Columbus: The Ohio State University.

18. Zhang, L., Yang, K. H., King, A. I. (2001). Comparison of brain responses between frontal and lateral impacts by finite element modeling. Journal of Neurotrauma, 18(1), 21-30.

19. Atsumi, N., Nakahira, Y., Iwamoto, M., Hirabayashi, S., Tanaka, E. (2016). Constitutive modeling of brain parenchyma taking account of strain rate dependency with anisotropy and application to brain injury analyses (No. 2016-01-1485). SAE Technical Paper. DOI: 10.4271/2016-01-1485, 13p.

20. Atsumi, N., Nakahira, Y., Tanaka, E., Iwamoto, M. (2018). Human brain modeling with its anatomical structure and realistic material properties for brain injury prediction. Annals of Biomedical Engineering, 46(5), 736-748. DOI: 10.1007/s10439-018-1988-8

21. Fernandes, F. A., Tchepel, D., Alves de Sousa, R. J., Ptak, M. (2018). Development and validation of a new finite element human head model: Yet another head model (YEAHM). Engineering Computations, 35(1), 477-496. DOI: 10.1108/EC-09-2016-0321

22. Wang, F., Han, Y., Wang, B., Peng, Q., Huang, X., Miller, K., Wittek, A. (2018). Prediction of brain deformations and risk of traumatic brain injury due to closed-head impact: Quantitative analysis of the effects of boundary conditions and brain tissue constitutive model. Biomechanics and Modeling in Mechanobiology, 17(4), 1165-1185. DOI: 10.1007/s10237-018-1021-z

23. Mao, H., Zhang, L., Jiang, B., Genthikatti, V. V., Jin, X., Zhu, F., Makwana, R., Gill, A., Jandir, G., Singh, A., Yang, K. H. (2013). Development of a finite element human head model partially validated with thirty five experimental cases. Transactions of the ASME. Journal of Biomechanical Engineering, 135(11), 111002-1- 111002-15.

24. Duckworth, H., Ghajari, M. (2019). Modelling brain biomechanics using a hybrid smoothed particle hydrodynamics and finite element model. In 2019 Ohio State University Injury Biomechanics Symposium, USA, 14 p. http://ibrc.osu.edu/wp-content/uploads/2019/05/2019-IBS-Manuscript_Duckworth.pdf.

25. Giudice, J. S., Zeng, W., Wu, T., Alshareef, A., Shedd, D. F., Panzer, M. B. (2019). An analytical review of the numerical methods used for finite element modeling of traumatic brain injury. Annals of Biomedical Engineering, 47(9), 1855-1872. DOI: 10.1007/s10439-018-02161-5

26. Horstemeyer, M. F., Berthelson, P. R., Moore, J., Persons, A. K., Dobbins, A., Prabhu, R. K. (2019). A mechanical brain damage framework used to model abnormal brain tau protein accumulations of National Football League players. Annals of Biomedical Engineering, 47(9), 1873-1888. DOI: 10.1007/s10439-019-02294-1

27. Berger, J., Horton, A., Joldes, G., Wittek, A., Miller, K. (2008). Coupling finite element and mesh-free methods for modelling brain deformation in response to tumour growth. In Computational Biomechanics for Medicine III MICCAI-Associated Workshop, 14 p. http://hdl.handle.net/10380/1383

28. Miller, K., Wittek, A., Joldes, G., Horton, A., Dutta-Roy, T., Berger, J., Morriss, L. (2010). Modelling brain deformations for computer-integrated neurosurgery. International Journal for Numerical Methods in Biomedical Engineering, 26(1), 117-138.

29. Miller, K., Joldes, G. R., Bourantas, G., Warfield, S. K., Hyde, D. E., Kikinis, R., Wittek, A. (2019). Biomechanical modeling and computer simulation of the brain during neurosurgery. International Journal for Numerical Methods in Biomedical Engineering, 35 10), e3250. DOI: 10.1002/cnm.3250

30. Chen, X., Sarntinoranont, M. (2007). Biphasic finite element model of solute transport for direct infusion into nervous tissue. Annals of Biomedical Engineering, 35(12), 2145-2158.

31. Wagner, A., Ehlers, W. (2010). Continuum-mechanical analysis of human brain tissue. PAMM, 10 (1), 99-100.

32. Støverud, K. H., Darcis, M., Helmig, R., Hassanizadeh, S. M. (2012). Modeling concentration distribution and deformation during convection-enhanced drug delivery into brain tissue. Transport in Porous Media, 92 (1), 119-143.

33. Bottaro, A., Ansaldi, T. (2012). On the infusion of a therapeutic agent into a solid tumor modeled as a poroelastic medium. Journal of Biomechanical Engineering, 134 (8), 084501.

34. Ehlers, W., Wagner, A. (2015). Multi-component modelling of human brain tissue: A contribution to the constitutive and computational description of deformation, flow and diffusion processes with application to the invasive drug-delivery problem. Computer Methods in Biomechanics and Biomedical Engineering, 18 (8), 861-879. DOI: 10.1080/10255842.2013.853754 
35. Fink, D., Wagner, A., Ehlers, W. (2018). Application-driven model reduction for the simulation of therapeutic infusion processes in multi-component brain tissue. Journal of Computational Science, 24, 101-115. DOI: 10.1016/j.jocs.2017.10.002

36. Ehlers, W., Wagner, A. (2019). Modelling and simulation methods applied to coupled problems in porousmedia mechanics. Archive of Applied Mechanics, 89(4), 609-628.DOI: 10.1007/s00419-019-01520-5

37. Cheng, S., Bilston, L. E. (2007). Unconfined compression of white matter. Journal of Biomechanics, 40(1), 117-124.

38. Budday, S., Nay, R., de Rooij, R., Steinmann, P., Wyrobek, T., Ovaert, T. C., Kuhl, E. (2015). Mechanical properties of gray and white matter brain tissue by indentation. Journal of the Mechanical Behavior of Biomedical Materials, 46, 318-330. DOI: 10.1016/j.jmbbm.2015.02.024

39. Miller, K., Chinzei, K. (2002). Mechanical properties of brain tissue in tension. Journal of Biomechanics, 35 (4), 483-490.

40. Hrapko, M., Van Dommelen, J. A. W., Peters, G. W. M., Wismans, J. S. H. M. (2006). The mechanical behaviour of brain tissue: Large strain response and constitutive modelling. Biorheology, 43 (5), 623636.

41. Forte, A. E., Gentleman, S. M., Dini, D. (2017). On the characterization of the heterogeneous mechanical response of human brain tissue. Biomechanics and Modeling in Mechanobiology, 16(3), 907-920. DOI: $10.1007 / \mathrm{s} 10237-016-0860-8$

42. Franceschini, G., Bigoni, D., Regitnig, P., Holzapfel, G. A. (2006). Brain tissue deforms similarly to filled elastomers and follows consolidation theory. Journal of the Mechanics and Physics of Solids, 54 (12), 2592-2620.

43. Zolochevskii, A. A. (1988). Modification of the theory of plasticity of materials differently resistant to tension and compression for simple loading processes. International Applied Mechanics, 24 (12), 12121217.

44. Zolochevskii, A. A. (1990). Method of calculating the strength of mine pipes formed from materials that behave differently under tension and compression. Strength of Materials, 22 (3), 422-428.

45. Mahnken, R., Schlimmer, M. (2005). Simulation of strength difference in elasto-plasticity for adhesive materials. International Journal for Numerical Methods in Engineering, 63 (10), 1461-1477.

46. Zolochevsky, A. A. (2007). On the choice of the invariants of the stress tensor in the refinement of the governing equations of solid mechanics for isotropic materials.Journal of the National Technical University «Kharkiv Polytechnic Institute». Series «Machine-building and CAD», (29), 58-64.

47. Lomakin, E. V. (2011) Constitutive models of mechanical behavior of media with stress state dependent material properties. InAltenbach H., Maugin G., Erofeev V. (eds.), Mechanics of Generalized Continua (vol. 7, pp. 339-350). Advanced Structured Materials.Berlin: Springer.

48. Beskopylny, A., Meskhi, B., Kadomtseva, E., Strelnikov, G. (2020). Transverse impact on rectangular metal and reinforced concrete beams taking into account bimodularity of the material. Materials, 13 (7), 1579-1-1579-14. DOI: 10.3390/ma13071579

49. Franceschini, G. (2006). The Mechanics of Human Brain Tissue. Ph. D. thesis, Trento: University of Trento.

50. Velardi, F., Fraternali, F., Angelillo, M. (2006). Anisotropic constitutive equations and experimental tensile behavior of brain tissue. Biomechanics and Modeling in Mechanobiology, 5(1), 53-61.

51. Hrapko, M., Van Dommelen, J. A., Peters, G. W., Wismans, J. S. (2008). The influence of test conditions on characterization of the mechanical properties of brain tissue. Journal of Biomechanical Engineering, 130(3), 031003.

52. Feng, Y., Okamoto, R. J., Namani, R., Genin, G. M., Bayly, P. V. (2013). Measurements of mechanical anisotropy in brain tissue and implications for transversely isotropic material models of white matter. Journal of the Mechanical Behavior of Biomedical Materials, 23, 117-132.

53. Schmidt, J. L., Tweten, D. J., Badachhape, A. A., Reiter, A. J., Okamoto, R. J., Garbow, J. R., Bayly, P. V. (2018). Measurement of anisotropic mechanical properties in porcine brain white matter ex vivo using magnetic resonance elastography. Journal of the Mechanical Behavior of Biomedical Materials, 79, 3037. DOI: 10.1016/j.jmbbm.2017.11.045

54. Haldar, K., Pal, C. (2018). Rate dependent anisotropic constitutive modeling of brain tissue undergoing large deformation. Journal of the Mechanical Behavior of Biomedical Materials, 81, 178-194. DOI: $10.1016 /$ j.jmbbm.2017.12.021

55. Kalra, P., Raterman, B., Mo, X., Kolipaka, A. (2019). Magnetic resonance elastography of brain: Comparison between anisotropic and isotropic stiffness and its correlation to age. Magnetic Resonance in Medicine, 82 (2), 671-679. DOI: 10.1002/mrm.27757 
56. Zolochevsky, A. A. (1982). Creep of Thin Shells for Materials with Different Behavior in Tension and Compression. Ph. D. Thesis, Kharkov: National Academy of Sciences of Ukraine, Institute of Mechanical Engineering Problems, 198 p.

57. Altenbach, H., Dankert, M., Zoločevskij, A. (1990). Anisotrope mathematisch-mechanische Modelle für Werkstoffe mit von der Belastung abhängigen Eigenschaften. Technische Mechanik, 11 (1), 5-13.

58. Zolochevsky, A. (1995). The formulation of constitutive equations for anisotropic materials with different behaviour in tension and compression. In Parker D. F. and England A. H. (eds.), IUTAM Symposium on Anisotropy, Inhomogeneity and Nonlinearity in Solid Mechanics (pp. 351-356). Dordrecht: Springer.

59. Zolochevsky, A. (1996). Identification of damage variable in ceramic matrix composite with different behaviour in tension and compression. In Fracture Mechanics of Ceramics (pp. 413-428). Boston: Springer.

60.Zolochevsky, A. A. (2007). On the choice of the anisotropy tensors in the refinement of the governing equations of solid mechanics for anisotropic materials. Journal of the National Technical University «Kharkiv Polytechnic Institute». Series «Machine-building and CAD», (29), 64-71.

61. Jones, R. M. (2009). Deformation Theory of Plasticity. Blacksburg: Bull Ridge Corporation, 640 p.

62. Treschev, A. A., Zhurin, E. A. (2020). Bending of ring plates, performed from an orthotropic nonlinear differently resistant material. International Journal for Computational Civil and Structural Engineering, 16 (1), 130-146. DOI: 10.22337/2587-9618-2020-16-1-130-146

63. Budday, S., Sommer, G., Birkl, C., Langkammer, C., Haybaeck, J., Kohnert, J., Bauer, M., Paulsen, F., Steinmann, P., Kuhl, E., Holzapfel, G. A. (2017). Mechanical characterization of human brain tissue. Acta Biomaterialia, 48, 319-340. DOI: 10.1016/j.actbio.2016.10.036

64. Chatelin, S., Constantinesco, A., Willinger, R. (2010). Fifty years of brain tissue mechanical testing: from in vitro to in vivo investigations. Biorheology, 47(5-6), 255-276.

65. Dodgson, M. C. H. (1962). Colloidal structure of brain. Biorheology, 1(1), 21-30.

66. Galford, J. E., McElhaney, J. H. (1970). A viscoelastic study of scalp, brain, and dura. Journal of Biomechanics, 3(2), 211-221.

67. Budday, S., Sommer, G., Holzapfel, G. A., Steinmann, P., Kuhl, E. (2017). Viscoelastic parameter identification of human brain tissue. Journal of the Mechanical Behavior of Biomedical Materials, 74, 463-476. DOI: 10.1016/j.jmbbm.2017.07.014

68. Budday, S., Sommer, G., Haybaeck, J., Steinmann, P., Holzapfel, G. A., Kuhl, E. (2017). Rheological characterization of human brain tissue. Acta Biomaterialia, 60, 315-329. DOI: 10.1016/j.actbio.2017.06.024

69. Prevost, T. P., Balakrishnan, A., Suresh, S., Socrate, S. (2011). Biomechanics of brain tissue. Acta Biomaterialia, 7 (1), 83-95.

70. Goriely, A., Geers, M. G., Holzapfel, G. A., Jayamohan, J., Jérusalem, A., Sivaloganathan, S., Squier, W., van Dommelen, J.A.W., Waters, S., Kuhl, E. (2015). Mechanics of the brain: Perspectives, challenges, and opportunities. Biomechanics and Modeling in Mechanobiology, 14 (5), 931-965. DOI: $10.1007 / \mathrm{s} 10237-015-0662-4$

71.Labus, K. M., Puttlitz, C. M. (2016). Viscoelasticity of brain corpus callosum in biaxial tension. Journal of the Mechanics and Physics of Solids, 96, 591-604. DOI: 10.1016/j.jmps.2016.08.010

72. Gorev, B. V., Rubanov, V. V., Sosnin, O. V. (1979). Creep of materials with different properties in tension and compression. Strength of Materials, 11 (7), 735-740.

73. Zolochevskij, A. A. (1988). Kriechen von Konstruktionselementen aus Materialien mit von der Belastung abhängigen Charakteristiken. Technische Mechanik, 9 (3), 177-184.

74.Zolochevsky, A. A. (1991). Creep of isotropic and anisotropic materials with different behaviour in tension and compression. In Zyczkowski M. (ed.), Creep in Structures (pp. 217-220).Berlin: Springer.

75. Altenbach, H., Schieße, P., Zolochevsky, A. A. (1991). Zum Kriechen isotroper Werkstoffe mit komplizierten Eigenschaften. Rheologica Acta, 30 (4), 388-399.

76. Mahnken, R. (2003). Creep simulation of asymmetric effects by use of stress mode dependent weighting functions. International Journal of Solids and Structures, 40 (22), 6189-6209.

77. Betten, J., Sklepus, A., Zolochevsky, A. (2003). A constitutive theory for creep behavior of initially isotropic materials sustaining unilateral damage. Mechanics Research Communications, 30 (3), 251-256.

78. Tsvelodub, I. (2012). Construction of constitutive equations of creep in orthotropic materials with different properties under tension and compression. Journal of Applied Mechanics and Technical Physics, 53 (6).

79. Banshchikova, I. A., Larichkin, A. Y. (2018). Torsion of solid rods with account for the different resistance of the material to tension and compression under creep. Journal of Applied Mechanics and Technical Physics, 59 (6), 1067-1077. DOI: 10.1134/S0021894418060123 
80. Ayata, C., Ropper, A. H. (2002). Ischaemic brain oedema. Journal of Clinical Neuroscience, 9 (2), $113-$ 124.

81. Walberer, M., Ritschel, N., Nedelmann, M., Volk, K., Mueller, C., Tschernatsch, M., Stolz, E., Blaes, F., Bachmann, G., Gerriets, T. (2008). Aggravation of infarct formation by brain swelling in a large territorial stroke: a target for neuroprotection? Journal of Neurosurgery, 109 (2), 287-293.

82. Raslan, A., Bhardwaj, A. (2007). Medical management of cerebral edema. Neurosurgical Focus, 22 (5), $1-12$.

83. Thiex, R., Tsirka, S. E. (2007). Brain edema after intracerebral hemorrhage: Mechanisms, treatment options, management strategies, and operative indications. Neurosurgical Focus, 22(5), 1-7.

84. Zolochevsky, A., Hop, J. G., Servant, G., Foosnæs, T., Øye, H. A. (2003). Creep and sodium expansion in a semigraphitic cathode carbon. In Crepeau P. N. (ed.), Light Metals (pp. 595-602). Warrendale: The Minerals, Metals and Materials Society.

85. Zolochevsky, A., Hop, J. G., Foosnæs, T., Øye, H. A. (2005). Surface exchange of sodium, anisotropy of diffusion and diffusional creep in carbon cathode materials. In Kvande H. (ed.), Light Metals (pp. 745750). San Francisco: The Minerals, Metals and Materials Society.

86.Zolochevsky, A. (2008). Degradation of perovskite-type ceramic membranes determined by defect chemistry modeling and chemically induced stress analysis. Journal of the National Technical University «Kharkiv Polytechnic Institute». Series «Machine-building and CAD», (2), 95-104.

87. Zolochevsky, A., Parkhomenko, L., Kühhorn, A. (2012). Analysis of oxygen exchange-limited transport and chemical stresses in perovskite-type hollow fibers. Materials Chemistry and Physics, 135 (2-3), 594603.

88. Zolochevsky, A., Grabovskiy, A. V., Parkhomenko, L., Lin, Y.S. (2013). Transient analysis of oxygen non-stoichiometry and chemically induced stresses in perovskite-type ceramic membranes for oxygen separation. Journal of the National Technical University «Kharkiv Polytechnic Institute». Series «Machine-building and CAD», (1), 179-189.

89. Crank, J. (1979). The Mathematics of Diffusion. Second Edition, New York: Oxford University Press, $414 \mathrm{p}$.

90.Zolochevsky, A., Tkachuk, N. N., Viricelle, J. P., Pijolat, C. (2007). Chemically induced stresses in the cathode of single chamber solid oxide fuel cell.Journal of the National Technical University «Kharkiv Polytechnic Institute». Series «Machine-building and CAD », (23), 148-157.

91.Zolochevsky, A. A., Goncharova, G. V., Minko, A.I., Shalashova, I. V. (2008). Modelling of diffusion induced stresses affected by the psychoactive media in the blood vessels of biomechanical system. Journal of the National Technical University «Kharkiv Polytechnic Institute». Series «Machine-building and CAD», (9), 90-97.

92. Eggen, C., Lin, Y. S., Goncharova, G., Zolochevsky, A. (2009). Diffusion characteristics of a supported lipid bilayer membrane on a dense cylindrical silica optical fibrous support. In 2009 AIChE Annual Meeting, Nashville, USA, $20 \mathrm{p}$.

93. Arifin, D. Y., Lee, L. Y., Wang, C. H. (2006). Mathematical modeling and simulation of drug release from microspheres: Implications to drug delivery systems. Advanced Drug Delivery Reviews, 58 (12-13), 1274-1325.

94. Elkin, B. S., Shaik, M. A., Morrison III, B. (2010). Fixed negative charge and the Donnan effect: a description of the driving forces associated with brain tissue swelling and oedema. Philosophical Transactions of the Royal Society A: Mathematical, Physical and Engineering Sciences, 368 (1912), 585603.

95. Lang, G. E., Stewart, P. S., Vella, D., Waters, S. L., Goriely, A. (2014). Is the Donnan effect sufficient to explain swelling in brain tissue slices? Journal of the Royal Society Interface, 11 (96), 20140123.

96. Lang, G. E. (2014). Mechanics of Swelling and Damage in Brain Tissue: A Theoretical Approach. Ph.D Thesis, Oxford: University of Oxford.

97. Hodgkin, A. L., Huxley, A. F. (1952). A quantitative description of membrane current and its application to conduction and excitation in nerve. The Journal of Physiology, 117 (4), 500-544.

98. Chen, H., Garcia-Gonzalez, D., Jérusalem, A. (2019). Computational model of the mechanoelectrophysiological coupling in axons with application to neuromodulation. Physical Review E, 99 (3), 032406-1-032406-18. DOI: 10.1103/PhysRevE.99.032406

99. Iwasa, K., Tasaki, I., Gibbons, R. C. (1980). Swelling of nerve fibers associated with action potentials. Science, 210 (4467), 338-339.

100.Galbraith, J. A., Thibault, L. E., Matteson, D. R. (1993). Mechanical and electrical responses of the squid giant axon to simple elongation.Transactions of the ASME. Journal of Biomechanical Engineering, 115, 13-22.

101.Akkin, T., Landowne, D., Sivaprakasam, A. (2009). Optical coherence tomography phase measurement 
of transient changes in squid giant axons during activity. Journal of Membrane Biology, 231 (1), 35-46.

102.Mosbacher, J., Langer, M., Hörber, J. K. H., Sachs, F. (1998). Voltage-dependent membrane displacements measured by atomic force microscopy. The Journal of General Physiology, 111 (1), 65-74.

103.Zhang, P. C., Keleshian, A. M., Sachs, F. (2001). Voltage-induced membrane movement. Nature, 413 (6854), 428-432.

104.Inoue, H., Mori, S. I., Morishima, S., Okada, Y. (2005). Volume-sensitive chloride channels in mouse cortical neurons: Characterization and role in volume regulation. European Journal of Neuroscience, 1 (6), 1648-1658.

105.Akita, T., Okada, Y. (2014). Characteristics and roles of the volume-sensitive outwardly rectifying (VSOR) anion channel in the central nervous system. Neuroscience, 275, 211-231.

106.Kachanov, L. M. (1958). On the rupture time under the condition of creep. Izvestiya Akademii Nauk SSSR. Otdelenie Tekhnicheskikh Nauk, (8), 26-31.

107.Rabotnov, Y. N. (1959). A mechanism of a long time failure. In Creep Problems in Structural Members (pp. 5-7). Moscow: USSR Academy of Science Publishing.

108. Chaboche, J. L. (1992). Damage induced anisotropy: On the difficulties associated with the active/passive unilateral condition. International Journal of Damage Mechanics, 1 (2), 148-171.

109.Altenbach, H., Altenbach, J., Zolochevsky, A. (1995). Erweiterte Deformationsmodelle und Versagenskriterien der Werkstoffmechanik. Stuttgart: Deutsher Verlag für Grundstoffindustrie, $172 \mathrm{~S}$.

110.Zolochevsky, A., Yeseleva, E., Ehlers, W. (2005). An anisotropic model of damage for brittle materials with different behavior in tension and compression. Forschung im Ingenieurwesen, 69(3), 170-180.

111.Zolochevsky, A. A., Sklepus, A. N., Sklepus, S. N. (2011). Nonlinear Solid Mechanics. Kharkiv: Garant, $719 \mathrm{p}$.

112.Bain, A. C., Meaney, D. F. (2000). Tissue-level thresholds for axonal damage in an experimental model of central nervous system white matter injury. Journal of Biomechanical Engineering, 122 (6), 615-622.

113. Lang, G. E., Vella, D., Waters, S. L., Goriely, A. (2015). Propagation of damage in brain tissue: Coupling the mechanics of edema and oxygen delivery. Biomechanics and Modeling in Mechanobiology, 14(6), 1197-1216. DOI: 10.1007/s10237-015-0665-1

114. Pogoda, K., Janmey, P. A. (2018). Glial tissue mechanics and mechanosensing by glial cells. Frontiers in Cellular Neuroscience, 12, 25/1-25/9. DOI: 10.3389/fncel.2018.00025

115.Franze, K., Janmey, P. A., Guck, J. (2013). Mechanics in neuronal development and repair. Annual Review of Biomedical Engineering, 15, 227-251.

116.Washizu, K. (1975). Variational Methods in Elasticity and Plasticity. Third edition, Oxford: Pergamon Press.

117.Zolochevskii, A. A. (1982). Allowance for differences in strain resistance in the creep of isotropic and anisotropic materials. Journal of Applied Mechanics and Technical Physics, 23 (4), 591-596.

118.Zolochevskii, A. A. (1985). Tensor relationship in the theories of elasticity and plasticity of anisotropic composite materials with different tensile and compressive strength. Mechanics of Composite Materials, 21(1), 41-46.

119.Zolochevskii, A.A. (1985). Determining equations and some problems of the variable-modulus theory of elasticity of anisotropic material. Journal of Applied Mechanics and Technical Physics, 26(4), 572-578.

120.Schwiedrzik, J. J., Wolfram, U., Zysset, P. K. (2013). A generalized anisotropic quadric yield criterion and its application to bone tissue at multiple length scales. Biomechanics and Modeling in Mechanobiology, 12 (6), 1155-1168.

121.Levrero-Florencio, F., Margetts, L., Sales, E., Xie, S., Manda, K., Pankaj, P. (2016). Evaluating the macroscopic yield behaviour of trabecular bone using a nonlinear homogenisation approach. Journal of the Mechanical Behavior of Biomedical Materials, 61, 384-396. DOI: 10.1016/j.jmbbm.2016.04.008

122.Panyasantisuk, J., Pahr, D. H., Zysset, P. K. (2016). Effect of boundary conditions on yield properties of human femoral trabecular bone. Biomechanics and Modeling in Mechanobiology, 15 (5), 1043-1053. DOI: 10.1007/s10237-015-0741-6

123.Schwiedrzik, J., Raghavan, R., Rüggeberg, M., Hansen, S., Wehrs, J., Adusumalli, R. B., Zimmermann, T., Michler, J. (2016). Identification of polymer matrix yield stress in the wood cell wall based on micropillar compression and micromechanical modelling. Philosophical Magazine, 9 (32-34), 34613478. DOI: $10.1080 / 14786435.2016 .1235292$

124.Levrero-Florencio, F., Manda, K., Margetts, L., Pankaj, P. (2017). Effect of including damage at the tissue level in the nonlinear homogenisation of trabecular bone. Biomechanics and Modeling in Mechanobiology, 16 (5), 1681-1695. DOI: 10.1007/s10237-017-0913-7

125.Levrero-Florencio, F., Manda, K., Margetts, L., Pankaj, P. (2017). Nonlinear homogenisation of trabecular bone: Effect of solid phase constitutive model. Proceedings of the Institution of Mechanical Engineers. Part H: Journal of Engineering in Medicine, 231 (5), 405-414. 
DOI: $10.1177 / 0954411916676220$

126.Speed, A., Groetsch, A., Schwiedrzik, J. J., Wolfram, U. (2019). Extrafibrillar matrix yield stress and failure envelopes for mineralised collagen fibril arrays. Journal of the Mechanical Behavior of Biomedical Materials, 103563-1-103563-39. DOI: 10.1016/j.jmbbm.2019.103563

127.Stipsitz, M., Zysset, P. K., Pahr, D. H. (2019). Efficient materially nonlinear $\mu$ FE solver for simulations of trabecular bone failure. Biomechanics and Modeling in Mechanobiology, 19 (5), 861-874. DOI: $10.1007 / \mathrm{s} 10237-019-01254-\mathrm{x}$

128.Bertoldi, K., Bigoni, D., Drugan, W. J. (2008). Nacre: An orthotropic and bimodular elastic material. Composites Science and Technology, 68 (6), 1363-1375.

129.Sun, J. Y., Zhu, H. Q., Qin, S. H., Yang, D. L., He, X. T. (2010). A review on the research of mechanical problems with different moduli in tension and compression. Journal of Mechanical Science and Technology, 24 (9), 1845-1854.

130.Zolochevsky, A., Sklepus, S., Kozmin, Y., Kozmin, A., Zolochevsky, D., Betten, J. (2004). Constitutive equations of creep under changing multiaxial stresses for materials with different behavior in tension and compression. Forschung im Ingenieurwesen, 68 (4), 182-196.

131.Zolochevsky, A., Voyiadjis, G. Z. (2005). Theory of creep deformation with kinematic hardening for materials with different properties in tension and compression. International Journal of Plasticity, 21 (3), 435-462.

132.Voyiadjis, G. Z., Thiagarajan, G. (1995). An anisotropic yield surface model for directionally reinforced metal-matrix composites. International Journal of Plasticity, 11(8), 867-894.

133. Voyiadjis, G. Z., Zolochevsky, A. (1998). Modeling of secondary creep behavior for anisotropic materials with different properties in tension and compression. International Journal of Plasticity, 14(1011), 1059-1083.

134. Lv, J., Xiao, Y., Zhou, Y., Xie, Y. (2019). Characterization and modeling of the creep behavior of fiber composites with tension and compression asymmetry. International Journal of Mechanical Sciences, 170, 105340. DOI: 10.1016/j.ijmecsci.2019.105340

135.Voyiadjis, G. Z., Zolochevsky, A. (1998). Creep theory for transversely isotropic solids sustaining unilateral damage. Mechanics Research Communications, 25 (3), 299-304.

136.Cinelli, I., Destrade, M., Duffy, M., McHugh, P. (2017). Neurotrauma evaluation in a 3D electromechanical model of a nerve bundle. In 8th International IEEE/EMBS Conference on Neural Engineering (pp. 513-516). Shanghai: IEEE. DOI: 10.1109/NER.2017.8008402

137.Cinelli, I., Destrade, M., Duffy, M., McHugh, P. (2017). Electrothermal equivalent three-dimensional finite-element model of a single neuron. IEEE Transactions on Biomedical Engineering, 65(6), 13731381. DOI: 10.1109/TBME.2017.2752258

138.Squire, L., Berg, D., Bloom, F. E., Du Lac, S., Ghosh, A., Spitzer, N. C. (2012). Fundamental Neuroscience. Four Edition, Amsterdam: Academic Press, 1152 p.

139.Altenbach, H., Zolochevsky, A. (1991). Kriechen dünner Schalen aus anisotropen Werkstoffen mit unterschiedlichem Zug-Druck-Verhalten. Forschung im Ingenieurwesen, 57 (6), 172-179.

140.Zolochevskii, A. A. (1993). Nonlinear asymmetric deformation of composite shells formed from materials having different tensile and compressive strengths. International Applied Mechanics, 29 (11), 945-951.

141.Zolochevsky, A., Galishin, A., Sklepus, S., Voyiadjis, G. Z. (2007). Analysis of creep deformation and creep damage in thin-walled branched shells from materials with different behavior in tension and compression. International Journal of Solids and Structures, 44(16), 5075-5100.

142.Zolochevsky, A., Galishin, A., Kühhorn, A., Springmann, M. (2009). Transversal shear effect in moderately thick shells from materials with characteristics dependent on the kind of stress state under creep-damage conditions: Theoretical framework. Technische Mechanik, 29(1), 38-47.

143. Galishin, A., Zolochevsky, A., Kühhorn, A., Springmann, M. (2009). Transversal shear effect in moderately thick shells from materials with characteristics dependent on the kind of stress state under creep-damage conditions: Numerical modeling. Technische Mechanik, 29(1), 48-59.

144.Zolochevsky, A., Galishin, A., Sklepus, S., Parkhomenko, L., Gnitko, V., Kühhorn, A., Leyens, C. (2013). Benchmark creep tests for thermal barrier coatings. Journal of the National Technical University «Kharkiv Polytechnic Institute». Series «Machine-building and CAD», (23), 158-178.

145.Zolochevsky, A., Sklepus, S., Galishin, A., Kühhorn, A., Kober, M. (2014). A comparison between the 3D and the Kirchhoff-Love solutions for cylinders under creep-damage conditions. Technische Mechanik, 34 (2), 104-113.

146.Zolochevsky, A., Grabovskiy, A. V., Parkhomenko, L., Lin, Y. S. (2012). Coupling effects of oxygen surface exchange kinetics and membrane thickness on chemically induced stresses in perovskite-type membranes. Solid State Ionics, 212, 55-65. 
147.Zolochevsky, A., Becker, A.A. (2011). Introduction to ABAQUS. Kharkiv:Business Investor Group.

148.Zolochevsky, A., Martynenko, A., Kühhorn, A. (2012). Structural benchmark creep and creep damage testing for finite element analysis with material tension-compression asymmetry and symmetry. Computers and Structures, 100, 27-38.

\title{
НЕЙРОМЕХАНІЧНА ХАРАКТЕРИСТИКА ПОШКОДЖЕННЯ МОЗКУ У ЗВ'ЯЗКУ 3 ТРАВМОЮ ГОЛОВИ ТА ПАТОЛОГІЧНИМИ ЗМІНАМИ
}

\author{
Золочевський О. О., Мартиненко О. В.
}

Травматичним пошкодженням центральної нервової системи (головного та спинного мозку) приділяється значна увага через їх руйнівні соціально-економічні наслідки. Функціональне та морфологічне ураження мозку - найскладніше явище в організмі. Це основна причина втрати працездатності та смерті. Стаття містить в собі конституційне моделювання і обчислювальні дослідження для розуміння механічного та функціонального руйнування мозку, викликаного травматичними (травма голови) та патологічними (пухлина головного мозку) явищами, в рамках континуальної механіки пошкоджень мозку. Розвиток пошкодження мозку проаналізовано на рівні органа (мозку), тканини (білої та сірої речовини), та клітини (окремого нейрону). Механізми росту нейропошкоджень були визначені у зв'язку з травмою голови та пухлиною мозку. Проаналізовано набряк внаслідок електричної активності нервових клітин при електрофізіологічних порушеннях, i пружнопластична деформація та повзучість при механічному навантаженні мозку. Розроблено конституційні закони нейромеханічної поведінки в умовах значних деформацій, враховано асиметрію розтягування-стиснення, а також початкову анізотропію мозкової тканини. Деталі щодо впровадження інтегрованої нейромеханічної конституційної моделі, включаючи модель Ходжкіна-Хакслі для напруги, в ABAQUS, ANSYS та внутрішньо розроблене програмне забезпечення, розглядалися у формі комп'ютерних інструментів структурного моделювання для аналізу розподілу механічної напруги за часом у мозку, як у здорових так і хворих, а також для аналізу нейропошкоджень та прогнозування життя пацієнтів з патологічними змінами мозку. Результатом аналізу буде те, як нейромеханічні комп'ютерні симуляції, застосовувані для моделювання травми голови та терапії пухлини мозку, можуть допомогти медичним спеціалістам у прийнятті рішень під час планування та здійснення медичних операцій.

КЛЮЧОВІ СЛОВА: пошкодження мозку, нейромеханіка, травма голови, пухлина мозку, моделювання, симуляція

\section{ИНФОРМАЦІЯ ПРО АВТОРІВ}

Золочевський Олександр, д.техн.н., зав. лабораторії, НВО «Політех», вул. О. Яроша, 14, Харків, 61145, e-mail: zolochevsky55@ukr.net, ORCID ID: https://orcid.org/0000-0001-6632-4292

Мартиненко Олександр, д.фіз-мат.н., професор кафедри гігієни та соціальної медицини Харківського національного університету імені В.Н. Каразіна, пл. Свободи, 6, Харків, Україна, 61022, e-mail: Alexander.v.martynenko@karazin.ua, ORCID ID: https://orcid.org/0000-0002-0609-2220

\section{НЕЙРОМЕХАНИЧЕСКАЯ ХАРАКТЕРИСТИКА ПОВРЕЖДЕНИЯ МОЗГА В СВЯЗИ С ТРАВМОЙ ГОЛОВЫ И ПАТОЛОГИЧЕСКИМИ ИЗМЕНЕНИЯМИ}

\author{
Золочевский А. А., Мартыненко А. В.
}

Травматическим повреждениям центральной нервной системы (головного и спинного мозга) уделяется значительное внимание из-за их разрушительных социально-экономических последствий. Функциональное и морфологическое поражение мозга - самое сложное явление в организме. Это основная причина потери трудоспособности и смерти. Статья содержит в себе конституционное моделирование и вычислительные исследования для понимания механического и функционального разрушения мозга, вызванного травматическими (травма головы) и патологическими (опухоль головного мозга) явлениями, в рамках континуальной механики повреждений мозга. Развитие повреждения мозга проанализировано на уровне органа (мозга), ткани (белого и серого вещества), и клетки (отдельного нейрона). Механизмы роста нейроповреждений были определены в связи с травмой головы и опухолью мозга. Проанализированы распухание вследствие электрической активности нервных клеток при электрофизиологических нарушениях, и упругопластическое 
деформирование и ползучесть при механическом нагружении мозга. Разработаны конституционные законы нейромеханичного поведения в условиях значительных деформаций, учтена асимметрия растяжению-сжатию, а также начальная анизотропия мозговой ткани. Детали по имплементации интегрированной нейромеханической конституционной модели, включая модель Ходжкина-Хаксли для напряжения, в ABAQUS, ANSYS и внутренне разработанное программное обеспечение, рассматривались в форме компьютерных инструментов структурного моделирования для анализа распределения механических напряжений по времени в мозге у здоровых и больных, а также для анализа нейроповреждений и прогнозирования жизни пациента с патологическими изменениями мозга. Результатом анализа является то, как нейромеханические компьютерные симуляции, применяемые для моделирования травмы головы и терапии опухоли мозга, могут помочь медицинским специалистам в принятии решений при планировании и осуществлении операций.

КЛЮЧЕВЫЕ СЛОВА: повреждение мозга, нейромеханика, травма головы, опухоль мозга, моделирование, симуляция

\section{ИНФОРМАЦИЯ ОБ АВТОРАХ}

Золочевский Александр, д.техн.н., зав. лаборатории, НПО «Политех», ул. О. Яроша, 14, Харьков, 61145, e-mail: zolochevsky55@ukr.net, ORCID ID: https://orcid.org/0000-0001-6632-4292

Мартыненко Александр, д.физ-мат.н., профессор кафедры гигиены и социальной медицины Харьковского национального университета имени В. Н. Каразина, пл. Свободи, 6, Харьков, Украина, 61022, e-mail: Alexander.v.martynenko@karazin.ua, ORCID ID: https://orcid.org/0000-0002-0609-2220 